\title{
MUSICOFOBIA, MUSICOFILIA E FILOSOFIA. KANT E NIETZSCHE SOBRE A MÚSICA
}

\author{
Maria João Mayer Branco* \\ maria_joao_branco@yahoo.com
}

RESUMO $O$ presente estudo propõe-se questionar a alegada musicofobia de Kant comparando-a com a bem conhecida musicofilia de Nietzsche. A partir da análise das considerações, à primeira vista tão dispares, de ambos os filósofos sobre a música, procurar-se-á mostrar que tal disparidade é apenas aparente, pois, quer para Kant, quer para Nietzsche, a experiência de ouvir música relaciona-se de modo profundo com a experiência de pensar.

Palavras-chave Kant, Nietzsche, música, filosofia, sensação, pensamento.

ABSTRACT This paper aims to question Kant's alleged musicophobia by comparing it with Nietzsche's well-known musicophilia. By analysing the considerations of both philosophers about music, it will try to show that their opposition is only apparent inasmuch as, both for Kant as well as for Nietzsche, the experience of listening to music has deep affinities with the experience of thinking.

Keywords Kant, Nietzsche, music, philosophy, sensation, thought.

* Pesquisadora na Universidade Nova de Lisboa/Instituto de Filosofia da Linguagem. Artigo recebido em 18/07/2013 e aprovado em 1ㅇ/12/2013. 
O homem que não sabe reflectir não encontra satisfação numa música consonante.

Kant

quanto mais músico, mais filósofo

Nietzsche

\section{1}

O fraco interesse de Kant pela música é tão conhecido como a importância que Nietzsche concedeu a esta arte ao longo da sua vida e obra. De acordo com os seus biógrafos, Kant nunca mostrou especial gosto pela música, não tocava nenhum instrumento e parecia preferir fanfarras militares e canções populares à música erudita. ${ }^{1}$ Em contrapartida, como foi bem documentado, por exemplo, por Curt Paul Janz, ${ }^{2}$ a educação musical de Nietzsche permitiu-lhe apreciar, tocar e até compor música. Ao contrário de Kant, Nietzsche foi um conhecedor dos compositores mais importantes da história da música ocidental, frequentava concertos com regularidade e conhecia a partitura das peças que amava. A relação dos dois pensadores com a música parece, então, ter sido radicalmente oposta, dando lugar a duas perspectivas filosóficas antagónicas: para Kant, a música é a arte com menor valor artístico, enquanto Nietzsche escreve em "Ecce Homo" que sente a causa da música como a sua própria causa. ${ }^{3}$ Assim, se, no $\$ 51$ da terceira "Crítica", Kant defende que a música é um mero "jogo de sensações", ${ }^{4}$ para Nietzsche,

1 A este respeito, cf. as referências fornecidas por Herman Parret, nomeadamente a partir da obra de Jean Mistler, Kant intime, Paris, Grasset, 1985 in Parret, 1992.

2 Janz, 1978-1979. Cf. também a biografia mais recente publicada por Rüdiger Safranski, onde o autor defende que "se pode dizer que toda a filosofia de Nietzsche é a tentativa de deter [a música] na vida" e que "mesmo quando a música já terminara, Nietzsche queria, tanto quanto possível, fazer música com a linguagem, os pensamentos e os conceitos" (Safranski, 2005, p. 9).

3 "Ecce Homo", "O Caso Wagner", §1. Os textos de Nietzsche serão citados a partir da edição portuguesa das "Obras Escolhidas", Círculo de Leitores, 1996 (dirigida por António Marques). No caso dos textos que não se incluem nessa edição, segue-se a edição alemã, Sämtliche Werke, Kritische Studienausgabe, Band 1-15, herausgegeben von Giorgio Colli und Mazzino Montinari, Berlin, Deutscher Taschenbuch Verlag, Walter de Gruyter, 1999, que será citada pela sigla KSA e pelo número do volume seguido do número da página, assumindo-se plena responsabilidade pela tradução das passagens em causa.

4 As passagens da terceira "Crítica" de Kant serão citadas pelo título da obra seguido do número do parágrafo correspondente e seguir-se-á a tradução portuguesa: Kant, I. "Crítica da faculdade do juízo". Lisboa: Imprensa Nacional - Casa da Moeda, 1992 (Introdução de António Marques, tradução e notas de António Marques e Valério Rohden). Quanto às citações da "Antropologia", seguir-se-á o mesmo procedimento com referência à edição da Wissenschaftliche Buchgesellshaft: Kant, I. "Werke 10. Schriften zur Antrhopologie, Geschichtsphilosophie, Politik und Pädagogik." Zweiter Teil. Darmstadt: Wissenschaftliche Buchgesellshaft, 1983 (§18: pp. 450-451, §22: pp. 456-458). A tradução para português é da nossa inteira responsabilidade. 
pelo contrário, "sem música a vida seria um erro"; 5 e enquanto Kant defende que a música é apenas "transitória" e não deixa "sobrar algo para a reflexão", ${ }^{6}$ para Nietzsche a música "liberta o espírito", promovendo aquilo a que chamou o "pathos filosófico".?

Ora, apesar de estas indicações sugerirem um forte contraste entre as posições dos dois filósofos a respeito da música, no presente estudo propomonos desenvolver a hipótese de que tal contraste é, em larga medida, apenas aparente. Para tanto, analisaremos alguns aspectos da perspectiva de Kant acerca da música para tentar mostrar de que modo eles indicam uma relação desta com a linguagem e com o pensamento que não colide necessariamente com os argumentos apresentados por Nietzsche em sua defesa. Mais concretamente, partindo de uma comparação da perspectiva de Kant com dois parágrafos de "Humano, demasiado humano" e com algumas passagens de "O caso Wagner", ${ }^{8}$ procurar-se-á mostrar que, tanto para Kant, como para Nietzsche, a experiência de ouvir música se relaciona de modo profundo com a experiência de pensar. A verificar-se esta hipótese, esperamos que ela contribua para a rejeição das leituras que associam uma excessiva racionalidade à alegada indiferença de Kant pela música e um elemento de irracionalidade pseudo-dionisíaca à bem conhecida musicofilia de Nietzsche. Só essa rejeição permite, de resto, compreender o facto de, apesar da ignorância musical de Kant e da profunda relação de Nietzsche com a música, a reduzida atenção que os textos kantianos dedicaram a esta arte tenha exercido uma influência muito maior na história do pensamento musical do que todas as páginas que Nietzsche lhe dedicou. ${ }^{9}$

\section{2}

A desvalorização kantiana da música parece ter na sua origem um certo grau de amusia. As afirmações de Kant sobre a música sugerem indiferença do filósofo aos encantos desta última, quando não uma surdez ou incapacidade para apreciar aquela a que chama "a arte dos sons". O fenómeno da amusia foi analisado pelo neurocientista Oliver Sacks na obra "Musicofilia. Histórias

\footnotetext{
Götzen-Dämmerung, "Sprüche und Pfeile”, §33, KSA 6, p. 64.

"Crítica da faculdade do juízo", §53.

"O Caso Wagner", §1.

8 Uma versão alargada deste trabalho analisará os textos de Nietzsche mais extensivamente, não prescindindo, como aqui, e por óbvias limitações de espaço, de considerar a posição de Nietzsche em relação à metafísica schopenhaueriana da música.

9 Acerca da desproporção entre a influência de Kant no pensamento musical (em particular no formalismo musical de Hanslick) e o espaço que dedicou à música na terceira "Crítica", cf. Kivy, 1991, pp. 63-73.
} 
sobre a música e o cérebro", ${ }^{10}$ onde são relatados diversos casos de maior ou menor indiferença à música e referidos os famosos casos de surdez musical de Nabokov, Henry James, Tolstoi ou Darwin. De acordo com o neurocientista, dá-se o caso de muitos seres humanos carecerem das capacidades perceptivas e cognitivas que permitem apreciar a música, conseguindo, porém, sentir com ela um prazer intenso, sendo que outros, muito "musicais" e possuindo "bom ouvido", não dão muita importância ou valor à música. ${ }^{11} \mathrm{Na}$ verdade, o próprio Kant estava ciente deste estranho fenómeno e, no $§ 22$ da sua "Antropologia", escreveu que a ausência de ouvido musical é "uma doença difícil de explicar", na qual o sujeito é sensível aos sons, mas não às notas musicais.

Ora, nada indica que Kant identificasse em si próprio esta "doença", uma vez que compreendia o prazer que a música suscita, ainda que não a valorizasse grandemente. Tendo em conta algumas considerações expostas na "Crítica da faculdade do juízo" sobre a música, o caso de Kant apresentaria, porventura, mais sintomas de musicofobia do que de amusia, fenómenos que, ainda segundo Oliver Sacks, devem ser distinguidos, consistindo a primeira não numa indiferença, mas no medo ou aversão pela música. $\mathrm{O}$ neurocientista esclarece que a musicofobia pode estar relacionada tanto com o impacto emocional e com o poder que a música exerce sobre nós, como com uma variedade de "ataques musicogénicos" que chegam a incluir a perda total de consciência. ${ }^{12}$ Tal não foi certamente o caso de Kant, mas as suas considerações acerca da música parecem visar um análogo do impacto emocional referido por Sacks, ou seja, o elemento contrário à razão de que a música é também composta. Este último terá, aliás, suscitado igualmente a resistência de Freud aos prazeres da música, considerando-se o psicanalista um ser ganz unmusikalisch.$^{13}$ Numa tentativa de auto-análise, Freud admite que a "disposição racionalista, ou talvez analítica" do seu espírito o fazia revoltarse perante a ideia de ser comovido por alguma coisa sem conseguir explicar por que estava a ser afectado. ${ }^{14}$ Ou seja, Freud reconhecia e era sensível ao poder de comoção da música, mas temia esse mesmo poder, que considerava racionalmente inexplicável e do qual sentia ter de proteger o seu intelecto, furtando-se, em particular, à força sedutora que as melodias exercem sobre o espírito humano.

Também Kant associava a melodia ao aspecto da música mais contrário à razão, defendendo que ela é composta por meras sensações que nos afectam

10 Sacks, 2008.

11 Sacks, 2008, p. 288.

12 Cf. Sacks, 2008, p. 37 ss.

13 Sobre a relação de Freud com a música, cf. Castarède, 1998, pp. 133-137.

14 Freud, S. "O Moisés de Miguel Ângelo", citado por Sacks, 2008, pp. 294-295. 
subjectivamente e não por formas objectivas e universalmente apreciáveis. Não obstante, para Kant a música não está absolutamente privada do elemento formal que é o objecto próprio dos juízos de gosto puros, encontrando-se este último, não na melodia, mas na harmonia. ${ }^{15} \mathrm{~A}$ harmonia seria, como o fora para Rameau, o elemento matemático e científico da música e aquele que poderia legitimar algum interesse da razão por esta arte. Apesar disto, porém, Kant não parece conseguir decidir-se a valorizar a música em relação às restantes artes, mostrando-se hesitante quanto ao lugar ocupado pela arte dos sons na hierarquia das belas-artes. Tal hierarquia é estabelecida no $§ 51$ da terceira "Crítica", atribuindo à poesia o lugar cimeiro e à música o grau mais baixo. A música é, portanto, considerada por Kant como a arte com menor valor artístico e a razão disto é o facto de ser composta por sons sobre os quais não podemos dizer com certeza se são simplesmente impressões sensíveis que causam sensações agradáveis ou se consistem já num jogo belo de sensações cuja forma suscita comprazimento. Quer dizer, Kant hesita em classificar a música como uma bela-arte ou como uma mera "arte agradável" porque nela a forma não se distingue claramente da simples sensação. A música parece, então, oscilar entre o carácter privado da sensação e a exterioridade objectiva da sua forma. Assim, se por um lado Kant elogia a música como sendo uma arte formal - consistindo ela, portanto, num jogo formal ou belo -, por outro condena-a como um simples jogo de sensações que pertence apenas ao domínio do que é agradável.

A esta hesitação acresce ainda um aspecto nada abonatório para a música, decorrente daquilo que Kant chama a sua transitoriedade. Como escreve no §53 da terceira "Crítica", da música não sobra nada para a reflexão porque as suas impressões são "transitórias". Ao contrário das "artes da imagem e da forma", que têm um veículo de transmissão "duradouro", as impressões musicais são passageiras, dispersam-se imediatamente. Associado à agradabilidade dos sons musicais, este inconveniente reforça os motivos pelos quais a música ocupa o último lugar entre as belas-artes, cujo valor se mede pela cultura com que estas enriquecem o ânimo e o espírito. De acordo com o mesmo §53, enquanto nas artes figurativas o jogo livre da imaginação com o entendimento "oferece um produto que serve aos conceitos do entendimento como um veículo duradouro", a música apenas joga com sensações que só deixam uma impressão transitória. Ou seja,

15 Acerca da associação da harmonia musical à beleza formal e da melodia à agradabilidade subjectiva das sensações, associação decorrente da inscrição de Kant na famosa querela entre Rameau e Rousseau, cf. o belo estudo de Marques, 2011, pp. 25-42. 
como escreve Kant, a música não deixa "sobrar algo para a reflexão" porque não oferece produtos estáveis que perdurem no tempo, contribuindo para a cultura e para o enriquecimento do ânimo. Por conseguinte, se

se apreciar o valor das belas-artes segundo a cultura que elas alcançam para o ânimo e tomarmos como padrão de medida o alargamento das faculdades que na faculdade de julgar têm de concorrer para o conhecimento, então a música possui entre as belasartes o último lugar [...] porque ela joga apenas com sensações. ${ }^{16}$

Do ponto de vista da produção de objectos culturais que contribuem para o conhecimento, "as artes figurativas precedem-na de longe" uma vez que delas resulta "um produto que serve os conceitos do entendimento como um veículo durável para a sua unificação com a sensibilidade". ${ }^{17}$

Tudo isto parece justificar a desvalorização kantiana da música em relação às outras artes. E no entanto, se considerarmos as hesitações dos $\S \S$ 51 e 53 da "Crítica da faculdade do juízo" à luz do aspecto que Kant considera ser o mais decisivo acerca da música, elas parecem, de acordo com a nossa hipótese inicial, perder força. Esse aspecto é o seguinte: se da música, como afirma Kant, não sobra nada para a reflexão, isso não quer, contudo, dizer que ela não suscita pensamentos. Trata-se, então, de perceber como é isso possível num quadro em que o ingrediente sensível da música parece levar a melhor sobre o elemento de racionalidade que a sua composição possa conter.

Para compreender em que medida pode a música suscitar pensamentos e não apenas sensações, importa, porém, começar por considerar o que Kant afirma acerca da poesia. ${ }^{18}$ No $\S 53$ é dito que a poesia é a arte mais elevada porque "alarga o ânimo" e oferece à imaginação uma forma que suscita "uma profusão de pensamentos [einer Gedankenfülle] à qual nenhuma expressão linguística é inteiramente adequada". No entanto, acrescenta-se ainda, "se o que importa é o movimento do ânimo" - e, na verdade, parece que é isso que importa a Kant -, a Tonkunst vem imediatamente a seguir à poesia porque ela permite um Gedankenspiel, um jogo de pensamentos, que "move o ânimo do modo mais variado". Não comunicando conceitos, a música está livre para exprimir aquilo a que Kant chama "uma inominável profusão de pensamentos" [einer unnenbaren Gedankenfülle]. Este aspecto parece, portanto, autorizar a hipótese de que, apesar de todas as suas hesitações, Kant

16 "Crítica da faculdade do juízo", §53.

17 Ibidem.

18 É o que faz Arden Reed no artigo "The debt of disinterest: Kant's critique of music", que inspirou alguns aspectos da presente interpretação do texto de Kant. Cf. Cf. Reed, 1980, pp. 563-584. 
atribui à música algum valor e uma relação com a razão que não era evidente à partida. E tanto assim é que Kant chega ao ponto de, sempre no mesmo $§ 53$, considerar de modo muito surpreendente que a música é uma "linguagem". Mais concretamente ainda, Kant chama-lhe uma "linguagem universal de sensações compreensível a todos os homens" e ainda uma "linguagem dos afectos". A questão consiste, então, em saber como é que a música pode ser uma linguagem se ela não é conceptual, quer dizer, na medida em que ela é privada de conceitos. Ou seja, neste contexto é legítimo perguntar que tipo de linguagem tem Kant em mente, quando se refere a uma linguagem não conceptual, não discursiva, mas uma linguagem dos afectos, que ainda por cima é dita ser universal. Uma outra questão que se levanta tem a ver com o que pode a linguagem musical comunicar. Quer dizer, se a música é uma linguagem, importa esclarecer que tipo de comunicação permite ela, tratandose, como se trata, de uma linguagem de afectos e sensações. A resposta a esta questão irá, por sua vez, ajudar a esclarecer como relaciona Kant a música com o pensamento.

Ora, no §18 da "Antropologia”, Kant escreve igualmente que

a música, enquanto jogo regulado das sensações do ouvido, não impõe apenas à sensibilidade vital um movimento incrivelmente vivo e variado, mas uma nova força; ela forma, portanto, como que uma linguagem de puras impressões (privada de conceitos).

Acontece que o fortalecimento do ânimo é, como se referiu acima, precisamente aquilo que caracteriza na terceira "Crítica" a arte que ocupa a posição mais alta na hierarquia das artes, ou seja, a poesia. E o problema consiste, assim, em saber como pode Kant atribuir a mesma característica à arte discursiva por excelência e à arte não discursiva e privada de palavras e conceitos. A resposta tem de estar relacionada com a consideração de que, sendo embora uma linguagem dos afectos, a música é também uma "linguagem universal", quer dizer, uma linguagem que não se restringe verdadeiramente ao reino privado, não universal, da agradabilidade. A universalidade em causa na música está certamente ligada a um aspecto que ela partilha com a linguagem discursiva e para o qual Kant chama a atenção no $\$ 53$ da "Crítica da faculdade do juízo", a saber, a sonoridade. O que está em causa é a ideia de que, como Kant escreve nessa mesma passagem, "cada expressão da linguagem possui no conjunto um som que é adequado ao seu sentido". Este som, continua Kant, "denota mais ou menos um afecto daquele que fala e reciprocamente também o produz no ouvinte, incitando também neste último a ideia que é expressa na linguagem com tal som”. Ou seja, 
a ideia que é expressa na verbalização dos pensamentos comunica-se, não apenas pela sua significação propriamente linguística, quer dizer, conceptual ou semântica, mas pelo afecto patente no som das palavras proferidas por aquele que fala. Ao sentido é adequado, portanto, não apenas um conceito, mas um som que "denota um afecto" e à sonoridade do discurso verbal Kant chama "modulação" ou "linguagem universal das sensações compreensível a todos os homens". O que isto implica, em última análise, é que a modulação dos sons comunica ideias porque, diz Kant, "produz no ouvinte" o "afecto daquele que fala" e "incita [no ouvinte] a ideia que é expressa na linguagem por tal som". A universalidade desta linguagem não propriamente verbal ou infra-verbal não decorre, então, da sua natureza conceptual, mas da sonorização de afectos ou daquilo a que poderíamos chamar a sua modulação musical ou a sua musicalidade. A analogia entre linguagem e música é, assim, estabelecida por meio da ideia da sonorização dos afectos ou modulação e Kant conclui que

assim como a modulação é a linguagem universal das sensações [...], a música exerce esta linguagem na sua inteira ênfase, a saber como linguagem dos afectos, e comunica universalmente [...] a ideia estética de um todo interconectado de uma inominável profusão de pensamentos.

Estamos agora em condições de perceber como é que a ideia central da primeira parte da terceira "Crítica" se apresenta aqui em estreita relação com a arte dos sons, quer dizer, a ideia de que existem formas de universalidade que não dependem de conceitos determinados. Se a poesia, que é a forma mais elevada de arte, "alarga - de acordo com as palavras de Kant - o ânimo libertando a imaginação" e apresenta, diz Kant ainda, "uma profusão de pensamentos à qual nenhuma expressão linguística é inteiramente adequada", quer dizer, se a poesia comunica "universalmente" sem "conceitos determinados", Kant parece, contudo, sugerir que existe uma outra forma de comunicação universal sem conceitos determinados que está na base da poesia: a "linguagem dos afectos" ou a modulação do som na qual a música consiste. Assim, no $§ 53$ é explicitamente declarado que a arte dos sons "comunica ideias estéticas" e que estas "não são conceitos, nem pensamentos determinados". E é ainda neste contexto e neste sentido que Kant refere a relação entre a música e a vivificação do ânimo que acabara de atribuir à poesia: a música, diz ele, exprime "a ideia estética de um todo interconectado de uma inominável profusão de pensamentos". Quer dizer, a música "move o ânimo" criando afectos que são comunicados a outros e, por conseguinte, são sentidos por outros, suscitando nestes últimos ideias. O ânimo daquele que 
escuta entra, portanto, num Gedankenspiel, num "jogo de pensamentos", que se funda em sensações e afecções que a linguagem universal dos afectos the comunica.

É com esta ideia em mente que a nossa hipótese inicial segundo a qual, para Kant, existe uma relação importante entre música e pensamento parece ganhar pertinência, pois a conclusão a que chega no §53 é a de que a música é uma arte que dá que pensar. Voltemo-nos agora para Nietzsche, de modo a tentar mostrar que o mesmo tipo de relação entre música e pensamento se encontra na sua filosofia.

\section{3}

Para o nosso propósito, iremos concentrar-nos em particular em duas passagens de "Humano, demasiado humano I". Como é sabido, a redação desta obra acontece no período subsequente à ruptura de Nietzsche com Wagner. Alguns aforismos sobre a música ali publicados parecem sugerir que tal ruptura implicou também um afastamento da metafísica da música defendida por Schopenhauer, ${ }^{19}$ legitimando a tese de que, nesse período, Nietzsche aderira às teses do formalismo musical advogado por Eduard Hanslick, autor da obra "Do belo musical" e um importante opositor de Richard Wagner. ${ }^{20}$ Defendendo que a beleza ou unidade de uma obra musical é idêntica à sua forma sonora e portanto imanente à própria obra, Hanslick acusava Wagner de ter procurado a beleza e a unidade das suas peças em planos extra-musicais como o drama (ou seja, a narrativa, as palavras e o seu significado) e o plano das emoções e sentimentos que a música suscita nos ouvintes. ${ }^{21}$

Este tipo de considerações contra os planos extra-musicais na música é recorrente em "Humano, demasiado humano". Dois exemplos disso são os $\S \S$ 215 e 217 de "Humano, demasiado humano I", onde Nietzsche fala de "música dramática" e "música absoluta". ${ }^{22}$ De acordo com estas passagens, a "música dramática”, quer dizer, a música que é acompanhada por um texto, subestima a estrutura formal, estritamente sonora, da peça musical a favor do drama e, nessa medida, ela não representou o início de algo novo na história da música,

19 Uma indicação exemplar desse afastamento encontrar-se-ia, por exemplo, no §215 do primeiro volume da mesma obra, onde Nietzsche escreve: "Em si, nenhuma música é profunda, nem significativa, não fala da vontade ou da coisa em si."

20 É essa a tese de Éric Dufour, para quem a ideia de belo musical presente em "Humano, demasiado humano" é "totalmente hanslickiana". Cf. Dufour, 2005, em especial, Deuxième partie, Chap. IV, “La conception de la musique dans Humain trop humain", pp. 197-212.

21 Acerca da polémica entre Hanslick e Wagner, cf. Goehr, 2004, pp. 88-131.

22 Para um esclarecimento destes dois termos, cf. Dahlhaus, 2006. 
mas o consumar de um processo de decadência da sensibilidade musical em geral. Quer dizer, Nietzsche considera que a música dramática (e o drama wagneriano em particular) não foi uma inovação musical sem precedentes, conforme defendiam os seus partidários, porque, em rigor, ela socorria-se, por assim dizer, do elemento menos musical da música, ou seja, exercia o seu efeito a partir do elemento extra-musical no qual consiste propriamente o drama. Assim, esta música convocava menos o ouvido do que o entendimento, ou seja, dirigia-se menos à sensibilidade do que à capacidade de seguir a narrativa proposta pela obra em questão.

Ora, se tal acontece com a música dramática, onde os sons musicais se associam a palavras e a um texto, Nietzsche considera que, por seu lado, a "música absoluta" ou música que, ao contrário da música dramática, é puramente instrumental e portanto privada de conteúdos conceptuais e simbólicos, desvaloriza igualmente a percepção sensível dos sons a favor de uma forma "pura” ou puramente intelectual. No §215 Nietzsche escreve: “[...] a música absoluta é ou uma forma em si mesma [...] ou o simbolismo das formas falando ao entendimento sem poesia depois de ambas as artes terem estado unidas por muito tempo e a forma musical estar toda entretecida com fios conceptuais e sentimentais". A alternativa proposta é a seguinte: se a música absoluta ou puramente instrumental é "uma forma em si mesma", supõe-se que aquilo que os ouvintes escutam corresponde, nos termos de Hanslick, a "formas sonoras em movimento" 23 - ou ainda, nas palavras de Kant, à pura sonoridade, à pura "modulação" de sons; mas se, pelo contrário, a música absoluta for composta por um simbolismo das formas, ou seja, pela significação que se atribui a conjuntos de notas, então o seu conteúdo é extra-musical, ou seja, e em última análise, é um conteúdo que se acrescenta à simples composição musical. Neste segundo caso, como Nietzsche mostra no mesmo $\$ 215$, é o intelecto quem introduz significação nos sons que, assim, deixam de se dirigir aos ouvidos.

Opondo o prazer formal à compreensão simbólica, Nietzsche parece, então, propor um formalismo semelhante ao de Kant e Hanslick. Contudo, a concepção de Nietzsche é fundamentalmente diferente, quando não oposta, à de Kant. Enquanto para este último, como se viu acima, a forma é o que concede, por assim dizer, racionalidade à música, justificando o interesse do intelecto por esta e a sua relação com a reflexão estética, para Nietzsche, ao invés, a forma é o que impede a música de contribuir para a tendência deca- 
dente daquilo a que chama, no $\$ 217$ de "Humano, demasiado humano I", o processo de intelectualização dos ouvidos. Nesse texto Nietzsche defende que a história da música é a história da sua "des-sensibilização" (Entsinnlichung), ou seja, que ao longo da história da música os nossos ouvidos se tornaram cada vez mais "intelectuais". Isto significa que, paulatinamente, deixámos de nos satisfazer em saber o que é que uma peça de música "é" e fomos tendendo cada vez mais a "perguntar pela razão, pelo significado", ou seja, a perguntar o que é que ela significa, que sentimento ou ideia está a ser expresso por meio daqueles sons. Em consequência disso, o prazer formal, quer dizer, estritamente musical, foi-se perdendo, bem como a capacidade de ouvir, escreve Nietzsche na mesma passagem, "a distinção subtil entre dó sustenido e ré bemol". Os nossos ouvidos, acrescenta ainda, "tornaram-se grosseiros", isto é, incapazes de reconhecer o que não é conceptual, simbólico ou sentimental, ou melhor, incapazes, no fundo, de ouvir música. Nesta medida, a história da música afigura-se como a história da promoção do contrário da musicofilia, constituindo-se como o desenvolvimento de uma patologia: a "doença difícil de explicar" que, como se disse antes, Kant descreve no $\$ 22$ da sua "Antropologia" como uma sensibilidade aos sons que é insensível às notas musicais. A hipótese de Nietzsche corresponde, portanto, à ideia de que a música moderna suscita a incapacidade de ouvir música. E dizer isto é o mesmo que dizer que se trata de uma música que provoca a já descrita amusia - a qual traz, segundo Nietzsche, sérias consequências para o exercício da filosofia. Vejamos como.

A crítica à intelectualização dos ouvidos não decorre da adesão de Nietzsche ao formalismo musical, mas da ideia de que as nossas sensações devem ser tidas em consideração quando fazemos juízos acerca da música. Tal ideia insere-se, de resto, na tese mais geral segundo a qual as sensações são inseparáveis da actividade discursiva ou cognitiva do intelecto. Nietzsche condena, portanto, a subordinação da sensibilidade ao intelecto discursivo, subordinação essa que considera equivaler a uma perda de refinamento dos sentidos, e, muito em particular, dos ouvidos, que assim se tornam cada vez mais "grosseiros". Em consequência do processo de intelectualização dos sentidos que Nietzsche considera próprio da arte moderna, a sensibilidade e o intelecto deixam, então, de se complementar, quer dizer, de colaborar em igual medida na criação do prazer estético. Em termos kantianos, poder-se-ia formular esta situação dizendo que o jogo livre que alarga o ânimo se torna impossível. Claro que, ao contrário de Kant, Nietzsche nunca pensa no intelecto e na sensibilidade como duas faculdades distintas. Em rigor, as suas críticas à intelectualização dos sentidos são simplesmente coerentes com a tese do primeiro capítulo de "Humano, demasiado humano I", segundo a qual 
a sensação, o sentimento e o conceito estão sempre entrelaçados. A análise desenvolvida desde o primeiro parágrafo desta obra corresponde precisamente a uma demonstração de que as nossas sensações não se opõem aos conceitos. A verdade é antes que, de acordo com o $§ 15$, as nossas sensações e sentimentos aparecem quando "grupos complexos de pensamentos também aparecem". É por esta razão, prossegue Nietzsche, que chamamos aos nossos pensamentos "profundos" apenas na medida em que consideramos profundos os sentimentos que os acompanham. De modo ainda mais preciso, as sensações e os pensamentos, o sensível e o inteligível, pertencem ao mesmo plano, ao plano contínuo que é o único a que temos acesso. Esta é também a razão pela qual Nietzsche conclui, no §14, que as nossas sensações e disposições (Empfindungen und Stimmungen) não são, na realidade, "unidades simples", mas "complexos" de sentimentos e pensamentos. Dito de outro modo, para Nietzsche não existem nem sensações "puras", nem pensamentos "puros"; as sensações e os pensamentos coexistem na mistura complexa que constitui o ser humano enquanto tal, mistura essa, além do mais, que muda com o tempo, tem uma história e acontece num contexto cultural que se transforma continuamente.

Ora, sendo a música uma arte, quer dizer, uma criação humana, dela é também própria esta mistura. Quer dizer, se não existe tal coisa como sensações puras ou pensamentos puros, também não existe algo como uma música pura. Este é, aliás, o ponto de vista a partir do qual Nietzsche critica as interpretações formalistas e a defesa da autonomia da arte, visando, em particular, a tese de l'art pour l'art e a interpretação do estado estético como um estado de desinteresse. Não cabe aqui desenvolver as críticas de Nietzsche à concepção kantiana da beleza desinteressada, ${ }^{24}$ mas importa assinalar que a fraqueza que ele vê expressa na exigência kantiana do desinteresse na arte também está presente na arte moderna sempre que ela tenta transformar criações artísticas numa espécie de criações auto-referenciais, quer dizer, puras ou puramente formais no sentido hanslickiano do termo, que rejeita, como se disse acima, qualquer ingrediente extra-artístico. Para Nietzsche esta concepção da arte configura uma expressão ou um sintoma de decadência e de niilismo negador da vida, pois a arte não é nem auto-referencial, nem desinteressada, mas antes "o grande estimulante da vida". ${ }^{25}$

A tese do entrelaçamento entre sensação, sentimento e pensamento permite-nos, então, chegar à hipótese com que começámos, ou seja, à ideia de que 
a arte em geral e a música em particular alargam, não apenas o nosso modo de sentir, mas também o nosso modo de pensar. E para Nietzsche a música é, por excelência, a forma de arte que ensina, tanto as nossas sensações, como os nossos pensamentos, como diz o $\$ 222$ de "Humano, demasiado humano I", "a ir tão longe" que não podemos senão afirmar a vida. Se isto é verdade, e se, quando ouvimos música, o nosso prazer deve vir dos sentidos e não de um plano não musical ou conceptualmente determinado, tal prazer não deve, como se viu já, subordinar as sensações a conceitos. Mas do mesmo modo que a arte não deve subordinar as sensações a conceitos, Nietzsche defende que ela não deve fazer o inverso. Quer dizer, se critica a excessiva intelectualização dos sentidos, Nietzsche também rejeita qualquer tipo de subordinação do intelecto às sensações.

Em rigor, Nietzsche suspeitava tanto de um enfraquecimento da sensibilidade por meio do intelecto como do contrário, isto é, do enfraquecimento da força do intelecto por via de um estímulo excessivo da sensibilidade. A música moderna, especialmente a música de Wagner, ofereceu-lhe o exemplo mais claro desta última tendência para a extrema excitação dos sentidos, que impedia o ouvinte não só de sentir, mas também de pensar. Em Wagner Nietzsche encontrou ambas as debilidades. Por um lado, trata-se de uma música que promove a intelectualização dos ouvidos por meio do uso de "grandes símbolos", como é dito em "O Caso Wagner" (§6). Este uso tem como efeito a des-sensorialização da componente musical ou sonora da música por um excesso de significação dela mesma: a música deixa de ser apenas o que é, uma composição sonora dirigida aos ouvidos, e passa a significar "mais do que apenas música - infinitamente mais" (§10). Por outro lado, ao mesmo tempo que intelectualiza os ouvidos a música de Wagner faz também o contrário disso, ou seja, estimula maximamente a audição. Ao fazêlo, porém, esta música continua a merecer as críticas de Nietzsche, pois o que resulta desse estímulo excessivo não é um alargamento, mas um enfraquecimento da sensibilidade, desta vez por exaustão. Quer isto dizer que, dirigindose não apenas ao intelecto por meio do recurso a símbolos, mas também aos ouvidos que esses mesmos símbolos intelectualizam, e levando ao limite a sua capacidade de ouvir, a música de Wagner conduz ao esgotamento das possibilidades da sensibilidade auditiva, anestesiando os ouvidos de quem a escuta. Em virtude de uma excessiva estimulação sensorial, os ouvintes tornam-se, por assim dizer, surdos.

São essencialmente estas as razões que levam Nietzsche a considerar que Wagner é, por excelência, o artista da decadência, e a sublinhar o carácter doentio das suas obras e as consequências nefastas delas sobre a saúde dos 
que escutam. Trata-se de uma música que debilita tanto a sensibilidade dos ouvintes como o seu intelecto, porquanto a massiva carga de efeitos que a caracteriza esmaga quer os sentidos, quer os pensamentos de quem ouve. Dito de outro modo, o que Nietzsche descobre é que, além de promover a intelectualização dos sentidos, reduzindo ao mínimo a necessidade de efectivamente escutar, a música de Wagner suprime também a possibilidade de pensar. Como escreve Nietzsche, esta música exige do ouvinte apenas uma coisa: "Sobretudo, nenhum pensamento!" (CW 6).

Assim, em vez de convocar a participação do ouvinte, a música de Wagner suprime ou obstaculiza a capacidade de sentir e de pensar tornando aquele que a ouve um refém do estímulo contínuo de símbolos grandiosos e melodias infinitas. É, de resto, por esta razão que, ao contrário da música de Bizet, a de Wagner não liberta, mas aprisiona o espírito. Por seu lado, sendo o "oposto" da música wagneriana, a música de Bizet trata, diz Nietzsche no $§ 1$ de "O caso Wagner", o ouvinte como "inteligente" e até como "músico". E, comparando a música dos dois compositores, Nietzsche escreve que, ao escutar Bizet, inúmeros "pensamentos completamente diferentes correm pela minha cabeça o tempo todo...", fazendo-nos lembrar da inominável profusão de pensamentos a que Kant alude na "Crítica da faculdade do juízo". É neste contexto que Nietzsche formula a célebre pergunta:

Já alguém reparou que a música liberta o espírito? Dá asas ao pensamento? De que nos tornamos mais filósofos quanto mais nos tornarmos músicos?

Em jeito de conclusão, importa sublinhar dois aspectos. O primeiro é o de que o modo como Nietzsche contrasta a música de Bizet com a de Wagner retoma implicitamente as suas críticas à intelectualização dos sentidos e a sua tese de que as sensações, os sentimentos e os pensamentos são inseparáveis. O segundo é o de que Nietzsche vai tão longe na sugestão de que a música de Bizet está profundamente ligada com a experiência de pensar, que declara que ela faz de si "um filósofo melhor" ("O caso Wagner", §1). A música, como se disse já, "liberta o espírito" e "dá asas ao pensamento". Mas o pensamento que está aqui em jogo não é um pensamento puro ou absoluto, uma abstracção gerada por uma qualquer razão pura. Tal como Nietzsche escreve de modo explícito, o que a música suscita é aquela espécie de afecto pensante, se assim lhe podemos chamar, a que chama "o pathos filosófico". Só este último parece poder alargar o exercício da filosofia por meio de um jogo livre de pensamentos e afectos que, como se poderia também dizer, não se subordinam uns aos outros. Para usar as palavras de Kant no $\$ 53$ da terceira "Crítica", a música parece, portanto, indicar o caminho que vai "das sensações às 
ideias indeterminadas", ideias essas que irão depois procurar por determinação conceptual. É esta, no fundo, a ideia de Nietzsche quando escreve numa nota póstuma do ano 1881: "é impossível dizer a que ponto <muitas coisas> ainda não encontraram nenhuma palavra, nenhum pensamento - é isto que a nossa música prova, - e não que não se pode encontrar nenhuma palavra nem nenhum pensamento." 26

\section{Referências}

CASTARÈDE, M.-F. “A voz e os seus sortilégios”. Lisboa: Caminho, 1998.

DAHLHAUS, C. "L'idée de la musique absolue". Traduit de l'allemand par Martin Kaltenecker. Genève: Éditions Contrechamps, 2006.

DUFOUR, É. "L'esthétique musicale de Nietzsche". Villeneuve d'Ascq: Presses Universitaires du Septentrion, 2005.

GOEHR, L. "The Quest for Voice: Resituating Musical Autonomy". In: Goehr, L. The quest for voice. Music, Politics and the Limits of Philosophy. Oxford/New York: Oxford University Press, 2004.

HANSLICK, E. "Do belo musical. Um contributo para a revisão da estética da arte dos sons". Tradução de Artur Morão. Lisboa: Edições 70, 2002.

HEFTRICH, U. "Nietzsches Auseinandersetzung mit der 'Kritik der Ästhetischen Ureilskraft"”. Nietzsche-Studien, 20, pp. 238-266, 1991.

JANZ, C. P. "Friedrich Nietzsche. Biographie" (Band 1: "Kindheit, Jugend, die Basler Jahre" - Band 2: "Die zehn Jahre des freien Philosophen" - Band 3: "Die Jahre des Siechtums. Dokumente, Quellen und Register"). München: Carl Hanser-Verlag, 1978-1979.

KANT, I. "Werke 10. Schriften zur Antrhopologie, Geschichtsphilosophie, Politik und Pädagogik." Zweiter Teil. Darmstadt: Wissenschaftliche Buchgesellshaft, 1983. KANT, I. "Crítica da faculdade do juízo". Introdução de António Marques. Tradução e notas de António Marques e Valério Rohden. Lisboa: Imprensa Nacional - Casa da Moeda, 1992.

MARQUES, U. R. A. "Kant e as analogias musicais". Revista de Filosofia da Universidad Complutense de Madrid, Vol. 36, Nr. 2, pp. 25-42, 2011.

MEERBOTE, R. (ed.). "Kant's Aesthetics". Atascadero/California: Ridgeview Publishing Company, 1991.

MISTLER, J. "Kant intime". Paris: Grasset, 1985.

NIETZSCHE, F. "Obras Escolhidas de Nietzsche". Ed. António Marques. Lisboa: Círculo de Leitores, 1996. 
NIETZSCHE, F. "Sämtliche Werke". Kritische Studienausgabe in 15 Bänden. Herausgegeben von Giorgio Colli und Mazzino Montinari. München/Berlin/New York: Deutscher Taschenbuch Verlag, Walter de Gruyter, 1999.

PARRET, H. "Kant sobre a música”. Revista Argumento, Lisboa, Vol. II, Nr. 3-4, pp. 93-113, 1992.

RAMPLEY, M. "Nietzsche, aesthetics and modernity". Cambridge: Cambridge University Press, 2000.

REED, A. "The debt of disinterest: Kant's critique of music". MLN, Vol. 95, Nr. 3, German Issue, p. 563-584, Apr. 1980.

SACKS, O. "Musicofilia. Histórias sobre a música e o cérebro". Lisboa: Relógio d'Água, 2008.

SAFRANSKI, R. "Nietzsche. Biographie seines Denkens". Frankfurt am Main: Fischer Taschenbuch Verlag, 2005. 